\title{
CRREL
}

Research Report 218

\section{PHASE COMPOSITION OF FROZEN MONTMORILLONITE-WATER MIXTURES FROM \\ HEAT CAPACITY MEASUREMENTS}

by

Duwayne M. Anderson

MAY 1967

U.S. ARMY MATERIEL COMMAND

COLD REGIONS RESEARCH \& ENGINEERING LABORATORY HANOVER, NEW HAMPSHIRE

DA Task IV014501B 52 A 02

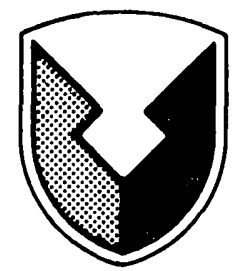




\section{PREFACE:}

This report was prepared by Dr. Duwayne Anderson, Head, Earth Sciences Group, Research Division ( $\mathrm{Mr}$. James A. Bender, Chief), U. S. Army Cold Regions Research and Engineering Laboratory.

USA CRREL is an Army Materiel Command laboratory. 
CONTENTS

Page

Preface-1.

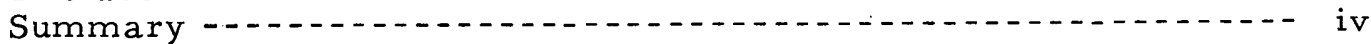

Introduction -

Theory - -

Apparatus and experimental methods

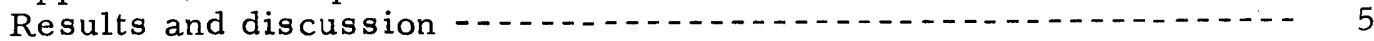

Conclusion - .

Literature cited

Figure

\section{ILLUSTRATIONS}

1. Schematic diagram of the Calvet Microcalorimeter-.-.--- 4

2. Heat capacity of frozen bentonite water mixtures in calories per degree of a sample containing one gram of clay---- 5

3. Total unfrozen water and unfrozen interlamellar water in sodium-bentonite -

Table

\section{TABLES}

I. Heat capacity of frozen bentonite-water mixtures at -4.7 and $-9.6 \mathrm{C} \ldots \ldots$

II. Specific heat of reference substances 6 


\section{SUMMARYY}

Equations are written that form the basis of a method for determining the unfrozen water content of frozen clay-water mixtures from heat capacity measurements. The heat capacity of frozen sodium-montmorillonite water mixtures was determined at -4.7 and $-9.6 \mathrm{C}$ with a Calvet Microcalorimeter. The data were then used in conjunction with the method described to obtain the unfrozen water content of these clay water mixtures. The data obtained indicate that the method is applicable at temperatures below about $-5 \mathrm{C}$. The amount of unfrozen water found in the frozen clay-water mixtures at -5 to $-10 \mathrm{C}$ is equivalent to an interfacial surface layer of water of from one to two molecular diameters in thickness. Most of this water can be accommodated and is thought to be located in interlamellar regions. 


\section{PHASE COMPOSITION OF FROZEN MONTMORILLONITE-WATER MIXTURES FROM HEAT CAPACITY MEASUREMENTS}

by

Duwayne M. Anderson

\section{INTRODUCTION}

It is well established that frozen clay-water mixtures contain a significant quantity of water that does not undergo an abrupt change in phase when the mixture is frozen or thawed; this water is commonly referred to as "unfrozen water." The amount and properties of the unfrozen water in frozen soil materials have been the topics of many investigations. It has been established that many factors are involved, but for a given soil material the amount of unfrozen water present is known to depend principally upon temperature and to a lesser extent upon pressure; except for very low water contents, it is virtually independent of the total water content. At a given temperature and pressure, the principal factors governing the unfrozen water content are the specific surface area of the soil, its chemical and mineralogical character, the number and kind of the exchangeable ions, and the species and concentrations of soluble substances present (Nersesova and Tsytovich, 1963). The liquid-like behavior of the unfrozen water has been inferred from the fact that transfer of water in frozen, water-saturated soil can be readily accomplished by the imposition of electrical or thermal gradients (Khakhimov, 1957; Nersesova and Tsytovich, 1963); the occurrence of electroosmosis in frozen soil recently was verified by Hoekstra and Chamberlain (1964).

Determinations of the amount of unfrozen water in frozen soil have been accomplished by: the dilatometer method (Buehrer and Aldrich, 1946); the calorimetric method (Nersesova and Tsytovich, 1963; Kolaian and Low, 1963); and an X-ray diffraction method (Anderson and Hoekstra, 1965). Although all three methods unquestionably establish the existence of substantial amounts of unfrozen water, they do not indicate the same quantity of unfrozen water in similar samples at a given temperature and pressure. Because the clay-adsorbed water has a density less than that of pure water in bulk (Anderson and Low, 1958), the dilatometer method yields values for the quantity of unfrozen water that probably are too high. Likewise, because the computations require the assumption that the specific heat and the latent heat of freezing the clay-adsorbed water are the same as for pure water in bulk, the calorimetric method as usually employed yields values that probably are too high (Martynov, 1956; Anderson, 1963). The X-ray diffraction method is applicable only to mixtures with water of 2:1 expanding lattice clay minerals. $\mathrm{Be}-$ cause the method cannot account for the possible existence of unf rozen water located outside the interlamellar space, it may underestimate the unfrozen water content. In general, it is found that unfrozen water contents for similar samples obtained by the three methods show deviations in accord with expectation; the higher values result from the dilatometer and calorimeter methods and lower values result from the $\mathrm{X}$-ray diffraction method.

This paper contains the results of heat capacity measurements made on frozen Wyoming bentonite-water mixtures previously studied by the X-ray diffraction method. It will be shown that the unfrozen water content of frozen mixtures of water and soil materials can be estimated from a determination of the heat capacity of the frozen mixtures as a function of total water content. For sodium-montmorillonite, the results derived from heat capacity measurements are consistent with the unfrozen water contents obtained by the $\mathrm{X}$-ray method. 


\section{THEORY}

A frozen clay-water mixture may be regarded as a two component system consisting of three phases viz., ice, unfrozen water and the clay particle matrix. Although the distinction is not actually necessary, the exchangeable ions will be regarded as belonging to the clay. The heat capacity of the system can be expressed as a sum of the heat capacities of the three phases plus an additional term accounting for the latent heat effect corresponding to the specified temperature change. Thus, immediately one can write

$$
Q=\left[\left(C_{c} M_{c}\right)+\left(C_{i} M_{i}\right)+\left(C_{u} M_{1}\right)\right] \Delta T+\int_{T_{1}}^{T_{2}} L\left(\frac{\partial M_{u}}{\partial T}\right) d T
$$

In eq $l, Q$ is the heat capacity per $g$ of mixture over the temperature interval $\Delta T$; $C_{C}, C_{i}$, and $C_{u}$ are the partial specific heat capacities of the clay, ice and unfrozen water, respectively; $M_{C}, M_{i}$, and $M_{u}$ are the weight fractions of the three phases, clay, ice and unfrozen water, respectively; and $L$ represents the latent heat of phase change of the unfrozen water. The last term accounts for the heat involved in the possible changes in relative amounts of ice and unfrozen water that accompany the temperature change, $\Delta T$. Since the total weight of water present may be written

$$
\mathrm{M}_{\mathrm{w}}=\mathrm{M}_{\mathrm{i}}+\mathrm{M}_{\mathrm{u}}
$$

eq 1 may be combined with eq 2 yielding

$$
Q=\left\{C_{i} M_{w}+\left[C_{C} M_{C}+M_{u}\left(C_{u}-C_{i}\right)\right]\right\} \quad \Delta T+\int_{T_{1}}^{T_{2}} L\left(\frac{\partial M_{u}}{\partial T}\right) d T .
$$

Dividing through by $\Delta \mathrm{T}$ and $\mathrm{M}_{\mathrm{c}}$ yields

$$
q=C_{i} w_{w}+\left[C_{c}+w_{u}\left(C_{u}-C_{i}\right)\right]+\frac{1}{\Delta T} \int_{T_{1}}^{T_{2}} L\left(\frac{\partial W_{u}}{\partial T}\right) d T
$$

in which $q$ is the heat capacity of the mixture per degree per unit weight of clay, $\mathrm{W}_{\mathrm{w}}$ is the total water content and $\mathrm{W}_{\mathrm{u}}$ is the unfrozen water content of the frozen mixture. Equation 4 is arranged to facilitate a discussion of the conditions under which the specific heat capacity of a frozen clay-water mixture may be linearly dependent on its total water content; obviously, it will be linear provided that the terms in brackets together with the last term do not vary with water content.

The first term in the brackets, the partial specific heat of the clay, can to a good approximation be regarded as independent of water content and, therefore, constant. Nersesova and Tsytovich (1963) maintain that the unfrozen water content, $\mathrm{W}_{\mathrm{u}}$, is practically independent of the total water content; according to them, it depends principally on temperature. Then for a given temperature, $W_{u}$ can be regarded as constant. Hence, the second term in brackets can be taken as constant if the difference between the partial specific heats of the ice and the unfrozen water does not change significantly with a change in water content. If the unfrozen water content itself does not vary with $\mathrm{W}_{\mathrm{w}}$ it is unlikely that a change in $\mathrm{W}_{\mathrm{w}}$ at constant temperature will cause a significant change in these two partial specific heats; therefore, the second term in brackets also may be taken as constant. 
The last term in eq 4 represents the heat of phase change accompanying any change in the ratio of unfrozen wate $r$ to ice due to the temperature fluctuation necessitated by the measurement itself. If the conditions of the measurement are kept invariant from sample to sample, the limits of integration, $T_{1}$ and $T_{2}$, will be the same and $\Delta \mathrm{T}$ must be constant. Finally, if it can be accepted that the amount of unfrozen water present is independent of the total water content and depends principally upon temperature then it may be accepted that the functional relationship between $\left(\frac{\partial W_{U}}{\partial T}\right)$ and $T$ and between $L$ and $T$ will, to a good approximation, be the same for each sample. Hence, it may be argued that the value of the last term in eq 4, to a good approximation, is independent of water content and may be regarded as constant. Thus it is established that as long as the foregoing assumptions are valid, a plot of the heat capacity (per unit weight of clay) of a frozen clay water mixture versus its total water content will yield a line having a slope equal to the partial specific heat capacity of the ice in the mixture and an intercept equal to the sum of the last two terms of eq 4. Moreover, it becomes apparent that the plot must depart from linearity when the water content decreases below the point at which the ice phase disappears, for at this point the amount of unfrozen water, $W_{u}$, no longer can be independent of water content.

Equation 4 then, offers a means of determining unfrozen water contents in frozenclay-water mixtures by determining the water content at which the ice phase disappears. This canbe accomplishedby determining the point at which plots of the heat capacityper g clay of frozen clay-water mixtures versus total water content depart from linearity. A check on the determination maybe madeby setting the extrapolated intercept equal to the sum of the last two terms in eq 4 and solving for $\mathrm{w}_{\mathrm{u}}$. The validity of this check, however, depends upon the validity of the values used in the computation; good estimates are possible but at present these values are not accuratelyknown.

\section{APPARATUS AND EXPERIMENTAL METHODS}

One pair of a four cell, Calvet Microcalorimeter was utilized to obtain the ratio of the heat capacity of frozen $\mathrm{Na}$-bentonite-water mixtures to that of mercury. Details of the construction and operation of the Calvet Calorimeter have been given by Calvet and Pratt (1963). A schematic diagram of the apparatus is shown in Figure 1. The instrument was operated in the differential mode to accomplish automatic compensation for minute variations in the internal jacket temperature of the calorimeter. About $2 / 3$ of the active thermopile was utilized in the measurements; the other $1 / 3$ was used to lower the sample temperature by means of the Peltie $r$ effect.

Sodium-saturated Wyoming bentonite was prepared by first suspending the raw clay in distilled water and allowing it to settle until particles larger than 1 micron (equivalent Stokes' law diameter) had settled out. The remaining suspension was then passed through a column of Amberlite IR-120 cation exchange resin that had previously been saturated with sodium ions. Care was taken to exclude small particles of resin in the effluent and the amount of clay passed through the column before regeneration was limited to $10 \%$ of the total exchange capacity of the column; the suspension was passed through the column drop by drop and subsequent analysis verified that exchange was nearly complete. The water content of the resulting homo-ionic bentonite suspensions was successively reduced in a pressure membrane apparatus. In this way, slurries and pastes of different water contents were prepared; these were then stored until needed in glass containers capped with Mylar film vapor barriers.

The heat capacity determinations proceeded as follows: A weighed sample of $\mathrm{Na}$-bentonite having a known water content (checked by a gravimetrical determination at the conclusion of the calorimetric measurement) was placed in a specially fitted stainless steel container and pressed into the sample receptacle of the calorimeter via the access tube. The temperature of the internal calorimeter jacket was 


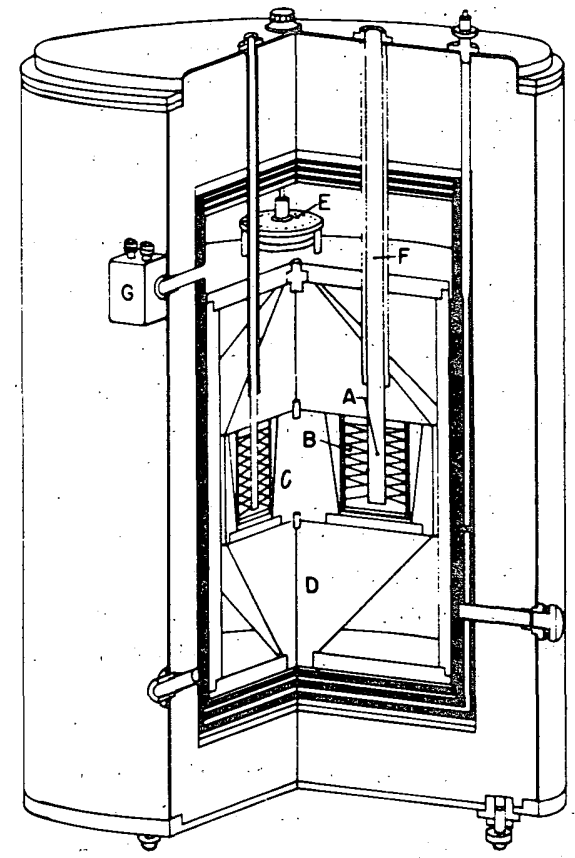

Figure 1. Schematic diagram of the Calvet Microcalorimeter showing the sample holder receptacle, A, and one of the thermopiles, B, that make up a microcalorimetric element. Two microcalorimetric elements are shown embedded in a massive aluminum block, C, capped by massive aluminum cones, D, shaped to optimize the equipartition of ambient thermal perturbations. The sensitivity of the apparatus is regulated by the switch, E, which taps all or a portion of each thermopile. The sample in a suitable container is placed in the sample holder receptacle through an access tube, $F$. The output of the thermopile is taken to a junction box, G. The interior of the calorimeter is thermostated and protected by several heat shields.

then fixed at a desired value. A DC current of exactly 2.50 ma was passed through $1 / 3$ of the active thermopile in the proper direction to cool the sample cell by the Peltier effect. Cooling was continued until a steady emf was read at the output of the remaining portion of the active thermopile. This output was always found to be $190 \pm 0.5 \mathrm{~V}$, corresponding to a difference in temperature between the sample and the massive surrounding aluminum heat sink of about $0.01 \mathrm{C}$.

Here it may be helpful to explain that when the steady Peltier current was turned on, the cell containing the sample began to cool; cooling continued until a steady state of heat transfer prevailed. At the steady state it can be seen that: (a) the temperature must be everywhere uniform within the sample; (b) for a given, constant Peltier current (i.e., a given rate of heat transfer), the difference, $\theta$, between the sample temperature and that of the massive aluminum heat sink must be the same regardless of the nature or amount of the cell contents; (c) on inter ruption of the Peltier current, a quantity of heat, $Q$, will be transferred from the heat sink. back into the cell as the value of $\theta$ decreases monotonically to zero; (d) the quantity of heat transferred will depend upon the nature and amount of the sample and upon the properties of the sample container and the calorimeter cell. For the Calvet microcalorimeter employed, the dependence of $Q$ on these factors was verified to be given by

$$
Q_{i}=\left(a+m_{i} c_{j}\right) \theta
$$

in which $\underline{a}$ is the calorimetric constant; $m_{i}$ is the sample weight, and $c_{j}$ is the specific heat capacity of the sample or a reference substance. $Q_{i}$ is proportional to the area under the curve resulting from a plot of $\theta$ versus time. By repeating the experiment under identical conditions, but with a different weight of the same sample and finally with a sample of a reference substance for which the specific heat capacity is known; a set of equations of the form of equation 5 result from which a and $\theta$ may be eliminated, giving the specific heat capacity of the unknown in term that of the reference substance.

At the moment the Peltier current to the sample cell was interrupted, $2 / 3$ of the thermopile was utilized in conjunction with a sensitive potentiometer to measure 
$\theta$ as a function of time. When $\theta$ had decayed to zeiu $\pm 0.5 \mathrm{~V}$ the Peltier current was reinstated and the above procedure was repeated twice. In this way, three sets of $\theta$ versus time data for the same sample under identical conditions were obtained. Subsequently, the above procedure was followed using three different weights of reagent grade mercury. Thus the required set of equations was obtained with two degrees of redundancy. Values of $Q$ were obtained from the numerical integration of the six sets of $\theta$ versus time data by means of a digital computer. These values were then used in conjunction with equation 5 to compute the specific heat capacity of the sample relative to that of mercury. The entire procedure was repeated at various temperatures and with samples of different water contents. As a check, the relative specific heat of aniline, crystalline and powdered ice was determined in the same way.

\section{RESULTS AND DISCUSSION}

Average values of the specific heat capacities of the frozen bentonite-water mixtures, with their respective standard deviations, and the heat capacity of mixtures containing one gram of clay calculated from these values are shown in Table I for sample temperatures of $-4.7 \mathrm{C}$ and $-9.6 \mathrm{C}$ (rounded to -5 and $-10 \mathrm{C}$ in the following discussion). * Table II is a comparison between handbook and observed values of the specific heat of aniline and ice at $0.3 \mathrm{C}$. It also contains the results of four separate determinations of the specific heat of theoven-dry clay. Figure 2 shows the data of Table I plotted according to eq 4.

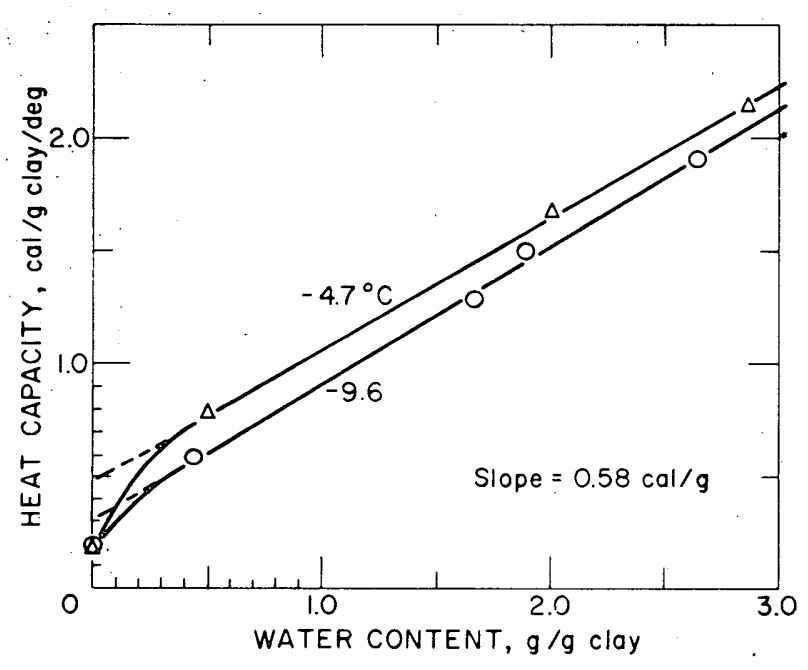

Figure 2. Heat capacity of frozen bentonite water mixtures in calories per degree of a sample containing one gram of clay.

* Data taken at temperatures near the freezing point were not reproducible. This could have been due to evaporation-condensation phenomena occurring within the sample container, since at temperatures near $0^{\circ}$ it was noticed at the end of the calorimetric measurements that small droplets of water were often found clinging to the walls at the top of the sample container. Another possibility arises from the fact that the last term in equation 4 becomes important at these temperatures. It could be that this contribution is not reproducible because of irreversibility over the small temperature increments employed. These data, therefore, are not reported. Meanwhile, further investigation is in progress and it is hoped that this question can be resolved. 
Table I. Heat capacity of frozen bentonite-water mixtures at -4.7 and $-9.6 C$.

\begin{tabular}{|c|c|c|c|c|}
\hline $\begin{array}{c}\text { Temperature } \\
\left({ }^{\circ} \mathrm{C}\right)\end{array}$ & $\begin{array}{l}\text { Water content } \\
\left(\mathrm{g} \mathrm{H}_{2} \mathrm{O} / \mathrm{g} \text { clay }\right)\end{array}$ & $\begin{array}{c}\text { Specific heat } \\
\text { of the mixture } \\
\text { (cal/g-sample/deg) }\end{array}$ & $\begin{array}{l}\text { Standard } \\
\text { deviation }\end{array}$ & $\begin{array}{c}\text { Heat capacity of the mixture } \\
\text { containing one gram of clay } \\
\text { (cal/g-clay/deg) }\end{array}$ \\
\hline & 0.500 & 0.523 & 0.018 & 0.785 \\
\hline-4.7 & 2.011 & 0.550 & 0.017 & 1.66 \\
\hline . & 2.922 & 0.545 & 0.017 & 2.14 \\
\hline : & 0.000 & 0.158 & 0.009 & 0.158 \\
\hline & 0.443 & 0.409 & 0.010 & 0.592 \\
\hline-9.6 & 1.662 & 0.483 & 0.012 & 1.29 \\
\hline$\theta$ & 1.888 & 0.519 & 0.016 & 1.50 \\
\hline & 2.648 & 0.520 & 0.013 & 1.90 \\
\hline
\end{tabular}

Table II. Specific heat of reference substances.

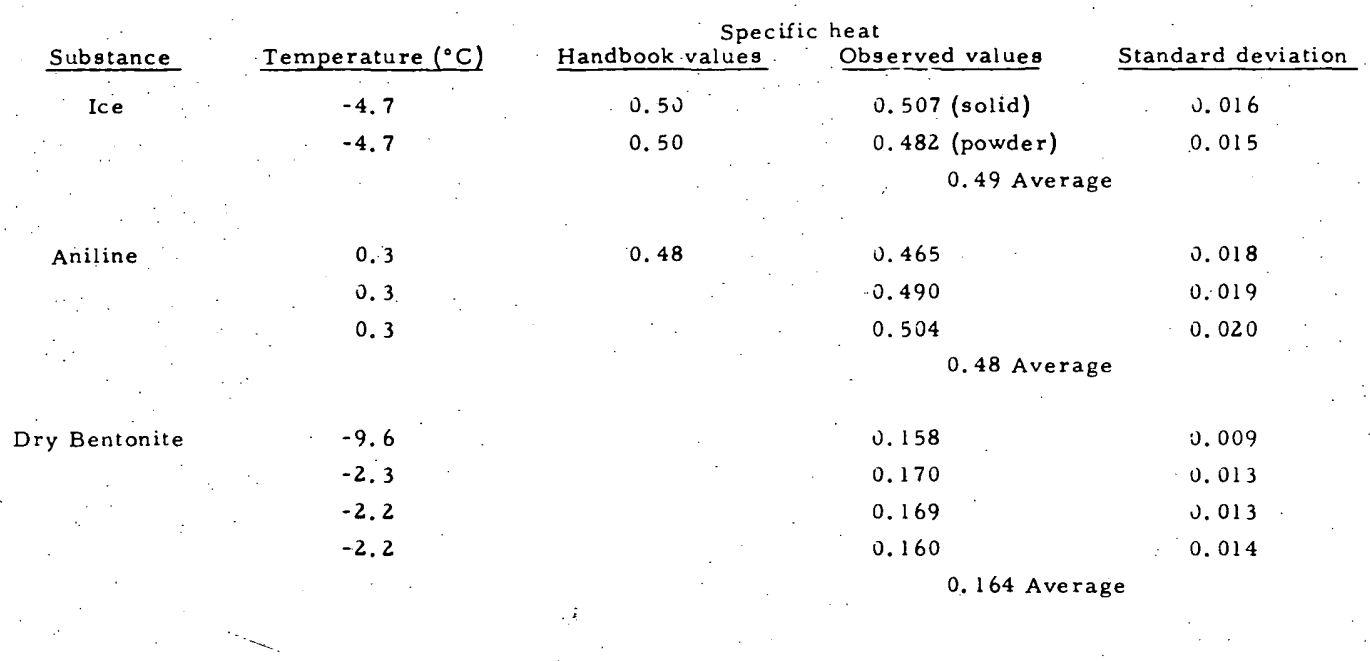

For water contents above about $0.5 \mathrm{~g}$ water per g clay the relationship between the heat capacity of the mixture per $g$ of clay and the total water content was found to be linear. This indicates that the unfrozen water content is practically independent of the total water content, verifying the opinion of Nersesova and Tsytovich cited above. The slopes of the linear portions of the curves in Figure 2 were found to be about $0.58 \mathrm{cal}$ per $\mathrm{g}$ water and the extrapolated intercepts of the linear portions were found to be about 0.30 and $0.46 \mathrm{cal} / \mathrm{g}$ clay/deg at -10 and $-5 \mathrm{C}$, respectively.

It has been shown that if a plot of the data is linear above a certain water content, an estimate of the unfrozen water content can be obtained by identifying the water content at which the curve departs from linearity. In Figure 2, the scarcity 
of data in the region of low water content contributes to the difficulty of precisely locating the point at which the curves become non-linear. More data would be desirable, but as is evident from the description of the apparatus and methods, the determinations were exceedingly time-consuming; for this reason it became impractical to obtain more experimental points at the two temperatures shown. However. Figure 2 shows sufficient data to see that for either line the point is less than $0.5 \mathrm{~g}$ water per g clay. Reasonable values are 0.3 and $0.4 \mathrm{~g}$ water per $\mathrm{g}$ clay for -10 and $-5 C$, respectively. If the last term of eq 4 is neglected, the intercepts of Figure 2 should correspond to the term in brackets. Taking the difference in the partial specific heats of ice and of the unfrozen water as $0.5 \mathrm{cal} / \mathrm{deg}-\mathrm{g}$, and taking the specific heat of the clay as $0.164 \mathrm{cal} / \mathrm{deg}-\mathrm{g}$, the unfrozen water. contents calculated from the intercepts are 0.59 and $0.27 \mathrm{~g}$ water per g clay at -5 and $-10 \mathrm{C}$, respectively. Although these values may be slightly in error since they depend on the accuracy of the specific heats used in the calculation and upon the validity of neglecting the last term in eq 4, the error is not likely to be large. It has been shown recently that the ice in frozen bentonite is present in the form of normal hexagonal crystals (Anderson and Hoekstra, 1965); hence, as a first approximation the value of the specific heat of bulk ice can be used for the partial specific heat of ice in eq 4 . Likewise, in view of the mobility of the unfrozen interfacial water in response to thermal and electrical gradients (Nersesova and Tsytovich, 1963; Hoekstra and Chamberlain, 1964), it is only reasonable in the temperature range of interest here to ascribe to it the properties of the liquid. Oster and Low (1964) determined the partial specific heat capacity of the surface-held, interfacial water in sodium-bentonitewater mixtures and showed that it ranged from about $1.0 \mathrm{cal} / \mathrm{g}-\mathrm{deg}$ in the very wet state to $1.1 \mathrm{cal} / \mathrm{g}-\mathrm{deg}$ in the nearly dry state. They explained the variation by reasoning that the increase in the partial specific heat capacity in the thinner surface water layers was due to the partial melting of structures in the liquid next to the clay surface. Now the unfrozen water in a frozen clay may be identified as the surface-held water that does not freeze and since the specific heat capacity of water is relatively insensitive to moderate changes in temperature and pressure, it is a safe assumption to take the partial specific heat capacity of the unfrozen water as approximately $1.0 \mathrm{cal} / \mathrm{g}$-deg. Finally, it should be emphasized that the unfrozen water contents calculated from the intercepts in Figure 2 using this value are consistent with unfrozen water contents found from the point at which the heat capacity-water content relationship departs from linearity.

In a preceding report (Anderson and Hoekstra, 1965) it was noted that conflicting data on the quantity of unfrozen water in frozen sodium-bentonite-water mixtures appear in the literature. Determinations at -5 and $-10 \mathrm{C}$ by dilatometric and calorimetric methods have yielded values as high as 0.99 and $0.86 \mathrm{~g}$ water unfrozen per $\mathrm{g}$ clay, respectively (Kolaian and Low, 1963; Buehrer and Aldrich, 1946). If $0.99 \mathrm{~g}$ unfrozen water per $g$ clay were present at $-5 \mathrm{C}$ one would expect in Figure 2 a line giving an extrapolated intercept of about 0.7 and the line would be expected to depart from linearity at a water content of 0.99 ; the data shown strongly argue against this. A similar calculation for an unfrozen water content of 0.86 at $-10 \mathrm{C}$ leads one to expect a line yielding an extrapolated intercept of 0.6 and showing curvature at a water content of 0.86 ; the data of Figure 2 clearly rule out this possibility.

The most complete unfrozen water content data presently available for a comparable sodium-bentonite are those of Nersesova and Tsytovich (1963) shown in Figure 3. The data were obtained by a calorimetric method, the details of which have not yet become available. Consequently, it is not possible to assess their method. Also shown in Figure 3 are the unfrozen, interlamellar water contents of frozen sodium-bentonite determined by the X-ray diffraction method (1965). Recalling that the $\mathrm{X}$-ray diffraction method may under-estimate the total unfrozen water content and accepting the data of Nersesova and Tsytovich, one would conclude from Figure 3 that salt-free, frozen sodium-bentonite-water mixtures at temperatures ranging from -5 to $-10 \mathrm{C}$ contain from 0.4 to $0.3 \mathrm{~g}$ unfrozen water per $\mathrm{g}$ clay. 


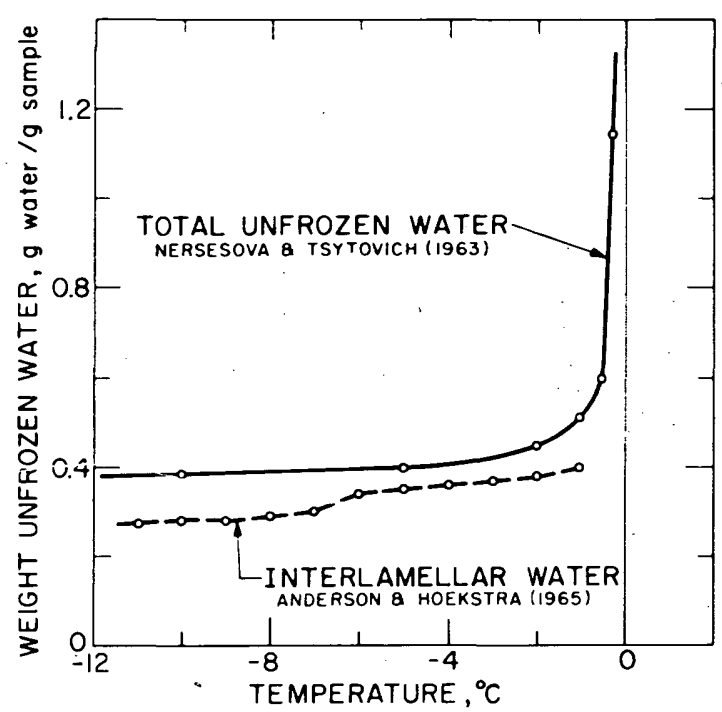

Figure 3. Total unfrozen water and unfrozen interlamellar water in sodium-bentonite. values of the intercepts of Figure 2; and unfrozen water contents calculated from the intercepts by neglecting the possibility of a heat effect due to change of phase yield values consistent with those obtained by other methods. One notes, however, that the intercept obtained at $-5 \mathrm{C}$ is larger than that obtained at $-10 \mathrm{C}$ and the unfrozen water content calculated from the intercept at $-5 \mathrm{C}$ therefore is higher. This is partly explained by the fact that, as the interlamellar spacings and calorimetric data show, there really is more unfrozen water at $-5 \mathrm{C}$ than at $-10 \mathrm{C}$. But according to the data of Figure 3, the value calculated from the intercept at $-5 \mathrm{C}(0.59 \mathrm{~g}$ unfrozen water per $g$ clay) is somewhat high. Hence it is possible that at $-5 \mathrm{C}$ the last term in eq 4 is becoming significant and could amount to as much as 0.1 calorie. The slopes of the lines drawn through the data of Figure 3 give $\frac{\partial W}{\partial T}$ and it is clear in any case that at temperatures above about $-2 \mathrm{C}$ the last term in eq 4 becomes dominant. The data of Williams (1964) illustrate this effect.

The slopes of the linear portions of the curves in Figure 2 are calculated to be about $0.58 \mathrm{cal} / \mathrm{g}$. According to eq 4 the slope should correspond to the partial specific heat of the ice in the mixture. Table II shows that the discrepancy between handbook and observed values and the value obtained from the slopes of the curves in Figure 2 is about $0.09 \mathrm{cal} / \mathrm{g}$. Although it is difficult to know exactly the error involved in evaluating slopes of the lines in Figure 2 it is possible that it may be as large as $\pm 0.1 \mathrm{cal} / \mathrm{g}$. An error of this magnitude is not large enough to change the foregoing estimates of the unfrozen water contents substantially but would account for the discrepancy. A more plausible explanation, however, is that the ice formed in the sample contains impurities; it is known that the effect of impurities in ice is to increase its apparent specific heat and that this effect is sufficient to account for the discrepancy (Dorsey, 1940).

\section{CONCLUSION}

In conclusion, a method that permits the determination of unfrozen water contents of salt-free, frozen, soil- and clay-water mixtures from their heat capacity has been derived and the assumptions and restrictive conditions required in the 
method have been discussed. The method was used successfully to estimate the unfrozen water contents of frozen sodium-bentonite pastes for comparison with values obtained by other methods. At -5 and $-10 \mathrm{C}$ the unfrozen water contents determined by this method are only slightly higher than the unfrozen, interlamellar water content determined on the same clay-water mixture by X-ray diffraction. The results also agree with the unfrozen water contents reported by Nersesova and Tsytovich (1963) and by Wu (1964) for comparable sodium bentonite clay-water mixtures. The data indicate that at -5 to $-10 \mathrm{C}$ the amount of unfrozen water present is equivalent to a surface-held layer of water only one or two molecular diameters in thickness, assuming that the water is uniformly distributed over the entire $\left(8 \times 10^{6} \mathrm{~cm}^{2} /\right.$ g) surface area of the clay. Most of this unfrozen water can be accommodated by, and is thought to be located in the interlamellar regions.

Although this method of determining unfrozen water contents is neither rapid nor easy, it is important because it offers an independent check of results obtained by the conventional dilatometric and calorimetric methods. Moreover, in writing the equations for the heat capacity of a frozen clay-water mixture, attention has been focused on the importance of studying the partial specific heat capacities of the three phases present and the last term of eq 4 . It has been pointed out in a thermodynamic argument (Anderson, 1963) that $L$ in eq 4 must vary with $W_{u}$ but as yet data giving this relationship directly are lacking. Work on these and related topics is now in progress.

\section{LITERATURE CITED}

Anderson, D. M. (1963) The latent beat of freezing soil water, Proceedings First International Conference on Permafrost. NRC-NAS Pub. No. 1287, p. 238-239.

and Hoekstra, P. (1965) Migration of interlamellar water during freezing and thawing of Wyoming bentonite, Soil Science Society of America, Proceedings, vol. 29, p. 498-504. USA CRREL Research Report 192.

and Low, P. F. (1958) The density of water adsorbed by lithiumsodium- and potassium-bentonite, Soil Science Society of America, Proceedings, vol. 22, p. 99-103.

Buehrer, T. F. and Aldrich, D. G. (1946) Studies in soil structure: VI Water bound by individual soil constituents as influenced by puddling, University of Arizona, Tech. Bull. no. 110.

Calvet, E. and Pratt, H. (1963) Recent progress in microcalorimetry. New York: Macmillan Company.

Dorsey, N.E. (1940) Properties of ordinary water substance. New York: Reinhold Pub. Corp.

Hemwall, J. B. and Low, P. F. (1955) The hydrostatic repulsive force in clay swelling, Soil Science, vol. 82, p. $135-145$.

Hoekstra, P. and Chamberlain, E. (1964) Electroosmosis in frozen soil, Nature, no. 203, p. 1406-1407.

Khakimov, Kh. R. (1957) Voprosy teorii i praktiki iskusstvennogo zamorazhivaniia gruntov (Theoretical and practical problems on artificial ground freezing). Moscow: Izd'vo Akad. Nauk. USA CRREL Draft Translation.

Kolaian, J. H. and Low, P. F. (1963) Calorimetric determination of unfrozen water in montmorillonite pastes, Soil Science, vol. 95, p. 376-383.

Martynov, G. A. (1956) Okalorimetricheskoi metodike opredeleniia kolichestva nezamerzshei vody v merzlykh gruntov (Calorimetric method of determining the amount of unfrozen water within frozen ground), Materialy k osnovam 


\section{LITERATURE CITED (Cont'd)}

ucheniia o merzlykh zonakh zemnoi kory, vol. III, p. 179-185. National Research Council of Canada, Ottawa, Technical Translation 1088.

Nersesova, Z.A. and Tsytovich, N.A. (1963). Unfrozen water in frozen soils, Contributions by the Russian delegation to the International Conference on Permafrost, N.A. Tsytovich, ed., Published by Acad. of Science, USSR, Moscow, 1963. English Translation in Proceedings, First International Conference on Permafrost, National Academy of Sciences - National Research Council, Publication no. 1287, p. 230-237.

Oster, J. D. and Low, P. F. (1964) Heat capacities of clay and clay-water mixtures, Soil Science Society of America, Proceedings, vol. 28, p. 605-609.

Williams, P. J. (1964) Experimental determination of apparent specific heats of frozen soils, Geotechnique, vol. 14, p. 133-142.

Wu, T. H. (1964) A nuclear magnetic resonance study of water in clay. Journal of Geophysical Research, vol. 69, p. 1083-1091. 


\section{Unclassified}

Security Classification

\section{DOCUMENT CONTROL DATA - R\&D}

(Security classification of title, body of abstract and indexing annotation must be entered when the overall report is classified)

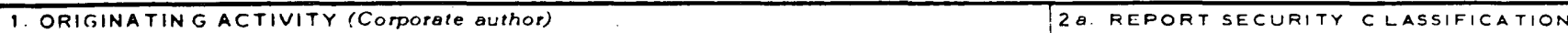

U.S. Army Cold Regions Research and

Engineering Laboratory, Hanover, N.H.

Unclassified

3. REPORT TITLE

PHASE COMPOSITION OF FROZEN MON TMORILLONITE-WATER MIXTURES FROM HEAT CAPACITY MEASUREMENTS

4. DESCRIPTIVE NOTES (Type of report and inclusive dates).

Research Report

5. AUTHOR(S) (Last name. first name, initial)

Anderson, Duwayne M.

\begin{tabular}{|l|l|l|l|l}
\hline 6. REPORT DATE & $7 a$. TOTALNO. OF PAGES & 7b. NO. OF REFS
\end{tabular}

May 1967

14

15

8a. CONTRACT OR GRANT NO.

9a. ORIGINATOR'S REPORT NUMBER(S)

b. PROJECT NO.

Research Report 218

c. DA Task 1VOl4501B52A02

9b. OTHER REPORT NO(S) (Any other numbers that may be assigned this report)

d.

10. AVAILABILITY/LIMITATION NOTICES This document is available to U.S. government agencies and their contractors from: Defense Documentation Center. Microfilm or photocopy of this document is available at cost of reproduction from: Clearinghouse for Federal Scientific and Technical Information.

11. SUPPL EMENTARY NOTES
12. SPONSORING MILITARY ACTIVITY

U.S. Army Cold Regions Research and Engineering Laboratory

13. ABSTRACT

Equations are presented which form the basis of a method for determining the unfrozen water content of frozen clay-water mixtures from heat capacity measurements. The heat capacity of frozen sodium-montmorillonite water mixtures was determined at -4.7 and $-9.6^{\circ} \mathrm{C}$ with a Calvet Microcalorimeter. The data were then used in conjunction with the method described to obtain the unfrozen water content of these clay water mixtures. The data obtained indicate that the method is applicable at temperatures below about $-5^{\circ} \mathrm{C}$. The amount of unfrozen water found in the frozen clay-water mixtures at -5 to $-10^{\circ} \mathrm{C}$ is equivalent to an interfacial surface layer of water of from one to two molecular diameters in thickness. Most of this water can be accommodated and is thought to be located in interlamellar regions. 


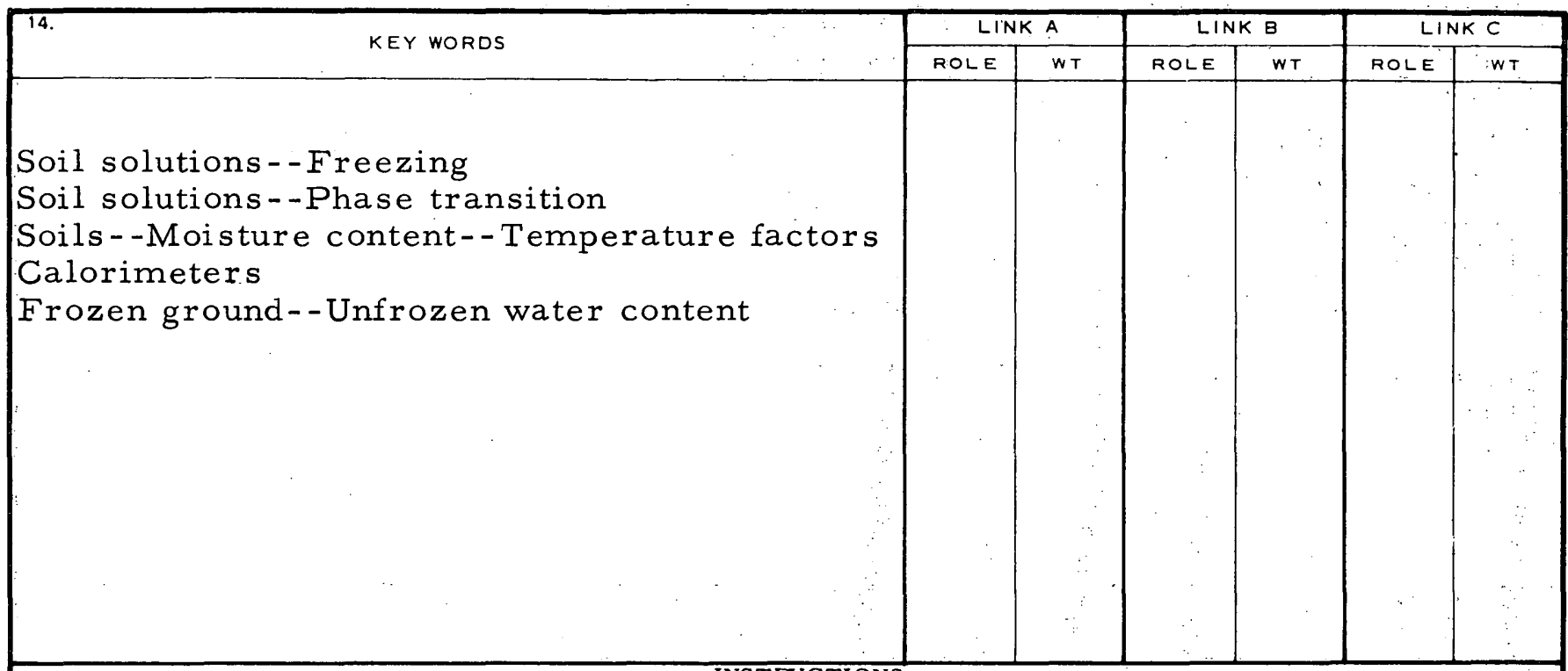

1. ORIGINATING ACTIVITY: Enter the name and address of the contractor, subcontractor, grantee, Department of $\mathrm{De}$ fense activity or other organization (corporate author) issuing the report.

2a. REPORT SECURTY CLASSIFICATION: Enter the overall security classification of the report. Indicate whether "Restricted Data" is included. Marking is to be in accordance with appropriate security regulations.

2b. GROUP: Automatic downgrading is specified in DoD Directive 5200.10 and Armed Forces Industrial Manual. Enter the group number. Also, when applicable, show that optional markings have been used for Group 3 and Group 4 as authorized.

3. REPORT TITLE: Enter the complete report title in all capital letters. Titles in all cases should be unclassified. If a meaningful title cannot be selected without classifica. tion, show title classification in all capitals in parenthesis immediately following the title.

4. DESCRIPTIVE NOTES: If appropriate, enter the type of report, e.g., interim, progress, summary, annual, or' final. Give the inclusive dates when a specific reporting period is covered.

5. AUTHOR(S): Enter the name(s) of author(s) as shown on or in the report. Enter last name, first name, middle initial. If military, show rank and branch of service. The name of the principal author is an absolute minimum requirement.

6. REPORT DATE: Enter the date of the report as day, month, year; or month, year. If more than one date appears on the report, use date of publication.

7a. TOTAL NUMBER OF PAGES: The total page count should follow normal pagination procedures, i.e., enter the number of pages containing information.

7b. NUMBER OF REF ERENCES: Enter the total number of references cited in the report.

8a. CONTRACT OR GRANT NUMBER: If appropriate, enter the applicable number of the contract or grant under which the report was written.

$8 b, 8 c, \& 8 d$. PROJECT NUMBER: Enter the appropriate military department identification, such as project number, subproject number, system numbers, task number, etc.

9a. ORIGINATOR'S REPORT NUMBER(S): Enter the official report number by which the document will be identified and controlled by the originating activity. This number must be unique to this report.

9b. OTHER REPORT NUMBER(S): If the report has been assigned any other report numbers (either by the originator or by the sponsor), al so enter this number(s).
10. AVAILABILITY/LIMITATION NOTICES: Enter any limitations on further dissemination of the report, other than those imposed by security classification, using standard statements such as:

(1) "Qualified requesters may obtain copies of this report from DDC."

(2) "Foreign announcement and dissemination of this report by DDC is not authorized."

(3) "U. S. Government agencies may obtain copies of this report directly from DDC. Other qualified DDC users shall request through

(4) "U. S. military agencies may obtain copies of this report directly from DDC. Other qualified users shall request through

-."

(5) "All distribution of this report is controlled. Qualified DDC users shall request through

.$"$

If the report has been furnished to the Office of Technical Services, Department of Commerce, for sale to the public, indicate this fact and enter the price, if known.

11. SUPPLEMENTARY NOTES: Use for additional explanatory notes.

12. SPONSORING MILITARY ACTIVITY: Enter the name of the departmental project of fice or laboratory sponsoring (paying for) the research and development. Include address.

13. ABSTRACT: Enter an abstract giving a brief and factual summary of the document indicative of the report, even though it may also appear elsewhere in the body of the technical report. If additional space is required, a continuation sheet shall be attached.

It is highly desirable that the abstract of classified reports be unclassified. Each paragraph of the abstract shall end with an indication of the military security classification of the information in the paragraph, represented as (TS), (S), (C), or $(U)$.

There is no limitation on the length of the abstract. However, the suggested length is from 150 to 225 words.

14. KEY WORDS: Key words are technically meaningful terms or short phrases that characterize a report and may be used as index entries for cataloging the report. Key words must be selected so that no security classification is required. Idenfiers, such as equipment model designation, trade name, military project code name, geopraphic location, may be used as key words but will be followed by an indication of technical context. The assignment of links, rules, and weights is optional. 